\title{
POLYGENIC VARIABILITY IN CHROMOSOMES OF DROSO- PHILA MELANOGASTER OBTAINED FROM THE WILD
}

\author{
B. J. HARRISON \\ John Innes Horticultural Institution, Bayfordbury, Hertford \\ and \\ K. MATHER \\ Department of Genetics, University of Birmingham
}

Received 27.ii.50

THE occurrence of heritable variation in wild populations of Drosophila species is now a commonplace. Flies which are trapped in the wild can be trusted to show genetic differences when suitably tested. Many of the variants to be found are traceable to single recessive mutant genes of large effect which are carried hidden in the heterozygous condition in the wild flies, revealing themselves when an inbreeding technique is used. These may be of the visible type, so called because they visibly affect some character of the fly, or they may be lethals or sublethals.

Other variation found in wild flies is less obviously traceable to single mutant genes, and indeed is almost certainly continuous in type and polygenic in inheritance. The variation in vigour and development found so plentifully by Dobzhansky in $D$. pseudo-obscura and $D$. persimilis is of this kind. Heritable continuous variation in the number of sternoplural chaetæ has been described in $D$. melanogaster by Wigan (I94I). It seems likely that the large response to selection for increased chaeta number which Wigan obtained in his Ockley population is due to the spread of a single major mutant, but the response to low selection in the Ockley population and the responses to both high and low selection in the Ealing population seem to be genuinely due to changes in polygenic systems.

The present experiment was undertaken to pursue further the question of polygenic variation in wild populations and in particular to gain some idea of the amount of variability existing within chromosomes, but balanced in such a way that the genotype would contain more variability than was displayed in the phenotype.

\section{THE METHOD OF EXPERIMENT}

Attention was concentrated on chromosome II, since this was the easiest to manage with the stocks available. Fourteen flies were obtained by Mr L. G. Wigan from an Essex apple dump in 1946 . Seven of the fourteen were found to carry lethals in their chromosome II's, one of them in fact having a lethal in each of its two chromosome 
II's. An eighth fly was heterozygous for a sterility gene in its chromosome II (Wigan, 1948).

TABLE IA

Data from the four homozygous lines

\begin{tabular}{|c|c|c|c|c|c|c|c|c|c|c|}
\hline \multirow{2}{*}{ Generation } & \multicolumn{2}{|c|}{$\mathrm{A} / \mathrm{A}$} & \multicolumn{2}{|c|}{$\mathbf{B} / \mathbf{B}$ (i) } & \multicolumn{2}{|c|}{ B/B (ii) } & \multicolumn{2}{|c|}{$\mathrm{C} / \mathrm{C}$} & \multicolumn{2}{|c|}{$\mathrm{D} / \mathrm{D}$} \\
\hline & $\mathrm{H}$ & L & $\mathbf{H}$ & L & $\mathbf{H}$ & L & $\mathbf{H}$ & L & $\mathbf{H}$ & L \\
\hline$F_{1}$ & \multicolumn{2}{|c|}{$\begin{array}{c}40 \cdot 15^{*} \\
6 \cdot 4 I\end{array}$} & \multicolumn{2}{|c|}{$\begin{array}{r}36 \cdot 80 \\
r \cdot 40\end{array}$} & \multicolumn{2}{|c|}{$\begin{array}{r}31 \cdot 15 \\
r \cdot 50\end{array}$} & \multicolumn{2}{|c|}{$\begin{array}{c}40 \cdot 98^{*} \\
5 \cdot 6_{4}\end{array}$} & \multicolumn{2}{|c|}{$\begin{array}{c}43 \cdot 46^{*} \\
6 \cdot 7 I\end{array}$} \\
\hline$F_{2}$ & \multicolumn{2}{|c|}{$\begin{array}{r}4 \mathrm{I} \cdot 45 \\
5 \cdot 90\end{array}$} & \multicolumn{2}{|c|}{$\begin{array}{r}36 \cdot 65 \\
5 \cdot 30\end{array}$} & \multicolumn{2}{|c|}{$\begin{array}{c}30.68 \dagger \\
0.65\end{array}$} & \multicolumn{2}{|c|}{$\begin{array}{r}40 \cdot 50 \\
5 \cdot 00\end{array}$} & \multicolumn{2}{|c|}{${ }_{6.03}^{4.43^{*}}$} \\
\hline$S_{1}$ & $\begin{array}{c}40 \cdot 97^{*} \\
6.07\end{array}$ & 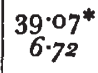 & $\begin{array}{r}3^{6 \cdot 53} \\
3.94\end{array}$ & $\begin{array}{r}35 \cdot 53 \\
2 \cdot 35\end{array}$ & $\begin{array}{r}32 \cdot 13 \\
1 \cdot 65\end{array}$ & $\frac{30.28}{-0.95}$ & $\begin{array}{c}40 \cdot 08 \\
5.95\end{array}$ & $\begin{array}{r}39.30 \\
6.30\end{array}$ & failed & $\begin{array}{c}45 \cdot 67^{*} \\
5 \cdot 7^{8}\end{array}$ \\
\hline $\mathrm{S}_{2}$ & $\begin{array}{c}40 \cdot 88 \\
7.55\end{array}$ & $\begin{array}{c}40 \cdot 65^{*} \\
4.25\end{array}$ & $\begin{array}{c}33.90^{*} \\
0.25\end{array}$ & $\begin{array}{c}37.30^{*} \\
0.89\end{array}$ & $\begin{array}{c}31 \cdot 13 \\
0.95\end{array}$ & $\begin{array}{r}31 \cdot 65 \\
r \cdot 30\end{array}$ & $\begin{array}{r}42 \cdot 05 \\
7 \cdot 20\end{array}$ & $\begin{array}{c}41 \cdot 13 \\
6 \cdot 05\end{array}$ & $\ldots$ & $\begin{array}{c}43.34 \\
6.92\end{array}$ \\
\hline $\mathrm{S}_{3}$ & $\begin{array}{c}41 \cdot 06^{*} \\
5 \cdot 32\end{array}$ & $\left\{\begin{array}{r}41 \cdot 65 \\
8 \cdot 30\end{array}\right.$ & $\begin{array}{r}35 \cdot 13 \\
3 \cdot 15\end{array}$ & $\begin{array}{c}36 \cdot 96^{*} \\
r \cdot 78\end{array}$ & $\begin{array}{c}32 \cdot 88 \\
2 \cdot 95\end{array}$ & $\begin{array}{r}3^{1} \cdot 93 \\
2 \cdot 35\end{array}$ & $\begin{array}{r}40 \cdot 28 \\
5 \cdot 75\end{array}$ & $\begin{array}{r}39.95 \\
6.40\end{array}$ & $\cdots$ & $\begin{array}{c}44 \cdot 98^{*} \\
I \cdot 20\end{array}$ \\
\hline$S_{4}$ & $\begin{array}{c}40 \cdot 28^{*} \\
7.66\end{array}$ & $\begin{array}{c}40.9 I^{*} \\
7.46\end{array}$ & $\begin{array}{c}36 \cdot 88 \\
2 \cdot 85\end{array}$ & $\begin{array}{r}34 \cdot 95 \\
3 \cdot 10\end{array}$ & $\begin{array}{c}30.93 \\
3.05\end{array}$ & $\begin{array}{r}30 \cdot 45 \\
-0.50\end{array}$ & $\begin{array}{r}40 \cdot 88 \\
6 \cdot 35\end{array}$ & $\begin{array}{c}40 \cdot 18 \\
6 \cdot 25\end{array}$ & $\ldots$ & $\begin{array}{c}42 \cdot 03 \dagger \\
-4 \cdot 45\end{array}$ \\
\hline $\mathrm{S}_{5}$ & $\begin{array}{c}40 \cdot 70 \dagger \\
7 \cdot 10\end{array}$ & $\begin{array}{c}40.99^{*} \\
4.63\end{array}$ & $\begin{array}{r}37.43 \\
2.95\end{array}$ & $\begin{array}{c}31 \cdot 66^{*} \\
2 \cdot 47\end{array}$ & $\begin{array}{r}30 \cdot 25 \\
1 \cdot 75\end{array}$ & $\begin{array}{c}30 \cdot 3^{8} \\
x \cdot 65\end{array}$ & $\begin{array}{r}40 \cdot 13 \\
6 \cdot 75\end{array}$ & $\begin{array}{r}40 \cdot 50 \\
4.70\end{array}$ & $\cdots$ & $\begin{array}{c}44.00^{*} \\
4.00\end{array}$ \\
\hline S6 & $\begin{array}{c}38 \cdot 84^{*} \\
6 \cdot 33\end{array}$ & $\begin{array}{c}39.95^{*} \\
7.4^{8}\end{array}$ & $\begin{array}{c}37.65^{*} \\
2.88\end{array}$ & $\begin{array}{c}32 \cdot 55 \\
0.70\end{array}$ & $\begin{array}{c}31 \cdot 10 \\
0.80\end{array}$ & $\begin{array}{c}30 \cdot 80 \\
-I \cdot 20\end{array}$ & $\begin{array}{r}39.20 \\
5.80\end{array}$ & $\begin{array}{r}40 \cdot 30 \\
6 \cdot 10\end{array}$ & $\cdots$ & $\cdots$ \\
\hline$S_{7}$ & failed & $\begin{array}{r}40.80 \\
6.90\end{array}$ & $\begin{array}{c}37 \cdot 33^{*} \\
4.44\end{array}$ & $\begin{array}{c}32 \cdot 08 \\
r \cdot 25\end{array}$ & $\begin{array}{c}32 \cdot 13^{*} \\
0.4 I\end{array}$ & 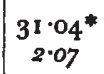 & $\begin{array}{r}4 \mathrm{I} \cdot 05 \\
6 \cdot 90\end{array}$ & $\begin{array}{r}40.93 \\
6 \cdot 05\end{array}$ & $\cdots$ & $\cdots$ \\
\hline S8 & $\ldots$ & $\begin{array}{r}40 \cdot 62 \\
5 \cdot 82\end{array}$ & $\begin{array}{r}37.40 \\
2.50\end{array}$ & $\begin{array}{r}32 \cdot 80 \\
0.50\end{array}$ & $\begin{array}{c}30 \cdot 25^{*} \\
1.50\end{array}$ & $\begin{array}{r}31 \cdot 25 \\
0.50\end{array}$ & $\begin{array}{c}40 \cdot 78 \\
5 \cdot 75\end{array}$ & $\begin{array}{r}40 \cdot 18 \\
4 \cdot 45\end{array}$ & $\cdots$ & $\cdots$ \\
\hline S9 & $\cdots$ & $\begin{array}{r}40 \cdot 25 \\
4 \cdot 60\end{array}$ & $\ldots$ & $\ldots$ & $\begin{array}{c}3 I \cdot 88 \\
0 \cdot 35\end{array}$ & $\begin{array}{l}\text { No } \\
\text { counts }\end{array}$ & ... & $\ldots$ & $\ldots$ & ... \\
\hline Sio & $\cdots$ & $\ldots$ & $\ldots$ & $\cdots$ & $\begin{array}{l}3^{2 \cdot} \cdot 90^{*} \\
-0.60\end{array}$ & $\begin{array}{c}30 \cdot 9 \\
r \cdot 60\end{array}$ & $\cdots$ & $\cdots$ & $\cdots$ & $\cdots$ \\
\hline$S_{11}$ & $\ldots$ & $\ldots$ & $\ldots$ & $\ldots$ & $\begin{array}{c}32 \cdot 90^{*} \\
4 \cdot 0 I\end{array}$ & $\begin{array}{r}31 \cdot 97 \\
2 \cdot 34\end{array}$ & $\ldots$ & $\cdots$ & $\cdots$ & $\cdots$ \\
\hline
\end{tabular}

The upper figure is the mean of the sex means

The lower figure is the difference of the sex means (female-male)

* Less than the full forty flies counted

$\dagger$ From a pool of the previous generation

A number of stocks were built up by $\mathrm{Mr}$ Wigan from these flies. Each stock was made homogenic for chromosomes X and III from the laboratory's standard Oregon inbred line: the stocks differed in chromosome II, each being deliberately made homozygous for a different chromosome II from the Essex population. No attempt was made to control chromosome IV. 
TABLE IB

Data from the six heterozygous lines

\begin{tabular}{|c|c|c|c|c|c|c|c|c|c|c|c|c|}
\hline \multirow{2}{*}{ 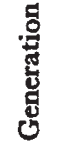 } & \multicolumn{2}{|c|}{$\mathrm{A} / \mathrm{B}$} & \multicolumn{2}{|c|}{$\mathrm{A} / \mathrm{C}$} & \multicolumn{2}{|c|}{$\mathrm{A} / \mathrm{D}$} & \multicolumn{2}{|c|}{$\mathrm{B} / \mathrm{C}$} & \multicolumn{2}{|c|}{ B/D } & \multicolumn{2}{|c|}{$\mathrm{C} / \mathrm{D}$} \\
\hline & $\mathrm{H}$ & L & H & $\mathrm{L}$ & $\mathrm{H}$ & L & $\mathbf{H}$ & L & $\mathbf{H}$ & $\mathbf{L}$ & $\mathbf{H}$ & L \\
\hline$F_{1}$ & \multicolumn{2}{|c|}{$\begin{array}{r}39 \cdot 45 \\
5 \cdot 30\end{array}$} & & \multicolumn{2}{|c|}{$\begin{array}{c}42 \cdot 85^{*} \\
3.59\end{array}$} & \multicolumn{2}{|c|}{$\begin{array}{c}38 \cdot 68 \\
6 \cdot 45\end{array}$} & \multicolumn{2}{|c|}{$\begin{array}{r}42.93 \\
2.85\end{array}$} & \multicolumn{2}{|c|}{$\begin{array}{c}42 \cdot 10 \\
5 \cdot 90\end{array}$} \\
\hline$F_{2}$ & \multicolumn{2}{|c|}{$\begin{array}{c}39 \cdot 00 \\
3 \cdot 10\end{array}$} & \multicolumn{2}{|c|}{$\begin{array}{r}40 \cdot 13 \\
5 \cdot 95\end{array}$} & \multicolumn{2}{|c|}{$\begin{array}{c}42 \cdot 70 \\
5 \cdot 90\end{array}$} & \multicolumn{2}{|c|}{$\begin{array}{r}39.28 \\
4.85\end{array}$} & \multicolumn{2}{|c|}{$\begin{array}{r}42 \cdot 53 \\
4 \cdot 25\end{array}$} & \multicolumn{2}{|c|}{$\begin{array}{r}42.23 \\
6.65\end{array}$} \\
\hline$S_{1}$ & $\begin{array}{r}39.73 \\
2.85\end{array}$ & $\begin{array}{c}40 \cdot 70 \\
4.70\end{array}$ & $\begin{array}{r}3^{8} \cdot 75 \\
5.80\end{array}$ & $\begin{array}{c}39 \cdot 58 \\
6 \cdot 45\end{array}$ & $\begin{array}{r}44.15 \\
6 \cdot 10\end{array}$ & $\begin{array}{r}41 \cdot 93 \\
4.65\end{array}$ & $\begin{array}{r}39 \cdot 3^{8} \\
4.95\end{array}$ & $\begin{array}{r}37.05 \\
5.50\end{array}$ & $\begin{array}{r}42 \cdot 75 \\
4 \cdot 40\end{array}$ & $\begin{array}{r}40 \cdot 73 \\
3 \cdot 45\end{array}$ & $\begin{array}{r}4 \mathrm{I} \cdot 70 \\
3 \cdot 90\end{array}$ & $\begin{array}{c}40 \cdot 38 \\
5.55\end{array}$ \\
\hline $\mathbf{S}_{2}$ & $\begin{array}{c}39 \cdot 10 \\
6 \cdot 30\end{array}$ & $\begin{array}{r}38 \cdot 15 \\
6 \cdot 10\end{array}$ & $\begin{array}{r}40 \cdot 10 \\
6 \cdot 40\end{array}$ & $\begin{array}{r}38 \cdot 68 \\
5 \cdot 35\end{array}$ & $\begin{array}{r}45 \cdot 13 \\
7 \cdot 55\end{array}$ & $\begin{array}{c}4 \mathrm{I} \cdot 08^{*} \\
7 \cdot 04\end{array}$ & $\begin{array}{r}39.85 \\
5.50\end{array}$ & $\begin{array}{c}37 \cdot 60 \\
3.80\end{array}$ & $\begin{array}{r}42 \cdot 63 \\
r \cdot 55\end{array}$ & $\begin{array}{r}40 \cdot 73 \\
4 \cdot 05\end{array}$ & $\begin{array}{r}44.05 \\
6.20\end{array}$ & $\begin{array}{c}38.98 \\
3.65\end{array}$ \\
\hline $\mathrm{S}_{3}$ & $\begin{array}{r}40 \cdot 30 \\
5 \cdot 20\end{array}$ & $\begin{array}{r}37.55 \\
4.00\end{array}$ & $\begin{array}{c}41 \cdot 58^{*} \\
7 \cdot 60\end{array}$ & $\begin{array}{c}39 \cdot 08 \\
6.65\end{array}$ & $\begin{array}{r}44 \cdot 88 \\
7 \cdot 65\end{array}$ & $\begin{array}{c}42 \cdot 00^{*} \\
4 \cdot 00\end{array}$ & $\begin{array}{r}40 \cdot 38 \\
5 \cdot 55\end{array}$ & $\begin{array}{r}37 \cdot 70 \\
5 \cdot 20\end{array}$ & $\begin{array}{r}43 \cdot 88 \\
4.75\end{array}$ & $\begin{array}{r}42 \cdot 23 \\
4.85\end{array}$ & $\begin{array}{r}42 \cdot 45 \\
7 \cdot 10\end{array}$ & $\begin{array}{c}38.93^{*} \\
5.13\end{array}$ \\
\hline$S_{4}$ & $\begin{array}{r}39 \cdot 98 \\
2 \cdot 35\end{array}$ & $\begin{array}{c}36 \cdot 98 \\
3 \cdot 75\end{array}$ & $\frac{40 \cdot 50 \dagger}{8 \cdot 80}$ & $\begin{array}{r}40 \cdot 63 \\
6 \cdot 35\end{array}$ & $\underset{8 \cdot I I}{46 \cdot 49^{*}}$ & $\begin{array}{c}40 \cdot 30 \dagger \\
5.80\end{array}$ & $\begin{array}{c}4 \mathrm{r} \cdot 60 \\
6 \cdot 60\end{array}$ & $\begin{array}{r}37.05 \\
4.80\end{array}$ & $\begin{array}{c}40 \cdot 3^{8} \\
5.05\end{array}$ & $\begin{array}{c}38 \cdot 70 \\
5 \cdot 20\end{array}$ & $\begin{array}{r}42.68 \\
7.65\end{array}$ & $\begin{array}{r}40.03 \\
5.55\end{array}$ \\
\hline$s_{5}$ & $\begin{array}{r}40 \cdot 63 \\
4.85\end{array}$ & $\begin{array}{c}38 \cdot 16^{*} \\
5.18\end{array}$ & ... & $\begin{array}{r}39 \cdot 05 \\
6.00\end{array}$ & $\begin{array}{r}48 \cdot 68 \\
8 \cdot 25\end{array}$ & $\begin{array}{c}37.49^{*} \\
9.63\end{array}$ & $\begin{array}{r}4 \mathrm{r} \cdot 35 \\
5 \cdot 70\end{array}$ & $\begin{array}{r}37 \cdot 15 \\
4 \cdot 40\end{array}$ & $\begin{array}{r}40 \cdot 08 \\
6 \cdot 35\end{array}$ & $\begin{array}{c}38 \cdot 18 \\
3 \cdot 25\end{array}$ & $\begin{array}{r}41 \cdot 60 \\
4 \cdot 5^{\circ}\end{array}$ & $\begin{array}{r}38 \cdot 70 \\
3 \cdot 70\end{array}$ \\
\hline S6 & $\begin{array}{c}38 \cdot 22^{*} \\
6.44\end{array}$ & $\begin{array}{c}38.75^{*} \\
3.50\end{array}$ & $\underset{39.90 \dagger}{6.60}$ & $\begin{array}{r}38 \cdot 75 \\
5.70\end{array}$ & $\begin{array}{c}46 \cdot 8 \mathrm{I}^{*} \\
7 \cdot 72\end{array}$ & $\begin{array}{c}37^{\circ} \cdot 67^{*} \\
9.33\end{array}$ & $\begin{array}{c}4 \mathrm{r} \cdot 53 \\
5 \cdot 05\end{array}$ & $\begin{array}{r}37 \cdot 40 \\
2 \cdot 10\end{array}$ & $\begin{array}{r}43.03 \\
4.55\end{array}$ & $\begin{array}{c}38 \cdot 68^{*} \\
6 \cdot 25\end{array}$ & $\begin{array}{r}42 \cdot 70 \\
5 \cdot 60\end{array}$ & $\begin{array}{r}37.53 \\
5.45\end{array}$ \\
\hline$S_{7}$ & $\begin{array}{c}41 \cdot 12^{*} \\
5 \cdot 4^{8}\end{array}$ & $\begin{array}{c}36 \cdot 18^{*} \\
5.25\end{array}$ & $\begin{array}{r}43 \cdot 15 \\
7 \cdot 40\end{array}$ & $\begin{array}{r}39 \cdot 03 \\
5.45\end{array}$ & $\begin{array}{c}49^{\circ} .07^{*} \\
4^{\circ} .44\end{array}$ & $\begin{array}{r}39 \cdot 73 \\
6 \cdot 15\end{array}$ & $\begin{array}{r}42 \cdot 13 \\
5 \cdot 15\end{array}$ & $\begin{array}{r}38 \cdot 30 \\
4 \cdot 40\end{array}$ & $\begin{array}{r}45.55 \\
4.90\end{array}$ & $\begin{array}{r}37.98 \\
7.57\end{array}$ & $\begin{array}{r}43 \cdot 10 \\
6 \cdot 60\end{array}$ & $\begin{array}{c}37 \cdot 81^{*} \\
5.49\end{array}$ \\
\hline S8 & $\begin{array}{c}40 \cdot 70^{*} \\
7 \cdot 40\end{array}$ & $\begin{array}{c}36.67^{*} \\
4.04\end{array}$ & $\begin{array}{r}4 \mathrm{r} \cdot 73 \\
8 \cdot 25\end{array}$ & $\begin{array}{c}38 \cdot 5^{8} \\
5 \cdot 55\end{array}$ & $\begin{array}{c}48 \cdot 40^{*} \\
8 \cdot 80\end{array}$ & $\begin{array}{c}37^{\circ} 49^{*} \\
5.82\end{array}$ & $\begin{array}{r}42.40 \\
5.30\end{array}$ & $\begin{array}{c}38 \cdot 18 \\
6 \cdot 25\end{array}$ & $\begin{array}{c}5 \mathrm{r} \cdot 25^{*} \\
6 \cdot 69\end{array}$ & $\begin{array}{r}39.03 \\
5.25\end{array}$ & $\begin{array}{r}44 \cdot 98 \\
3 \cdot 45\end{array}$ & $\begin{array}{c}37 \cdot 58 \\
5 \cdot 45\end{array}$ \\
\hline S9 & $\begin{array}{c}39 \cdot 4^{8} \\
5 \cdot 05\end{array}$ & $\begin{array}{r}36 \cdot 00 \\
3 \cdot 4^{8}\end{array}$ & $\begin{array}{r}4 \mathrm{r} \cdot 73 \\
6 \cdot 25\end{array}$ & $\begin{array}{c}39 \cdot 50 \\
4 \cdot 60\end{array}$ & $\cdots$ & $\cdots$ & $\begin{array}{r}4 \mathrm{r} \cdot 25 \\
5 \cdot 90\end{array}$ & $\begin{array}{c}37 \cdot 68 \\
5 \cdot 15\end{array}$ & $\ldots$ & $\begin{array}{c}36 \cdot 93 \\
5 \cdot 15\end{array}$ & $\cdots$ & $\cdots$ \\
\hline Sro & $\begin{array}{r}38 \cdot 55 \\
5 \cdot 40\end{array}$ & $\begin{array}{r}35 \cdot 80 \\
5 \cdot 10\end{array}$ & $\underset{8 \cdot 04}{43 \cdot 17^{*}}$ & $\begin{array}{c}38 \cdot 4^{8} \\
5 \cdot 15\end{array}$ & ... & $\cdots$ & $\begin{array}{r}42 \cdot 00 \\
5 \cdot 20\end{array}$ & $\begin{array}{c}37 \cdot 55 \\
3 \cdot 20\end{array}$ & $\cdots$ & $\ldots$ & $\ldots$ & $\ldots$ \\
\hline SII & $\begin{array}{r}37.75 \\
2.60\end{array}$ & $\begin{array}{r}35 \cdot 80 \\
4 \cdot 10\end{array}$ & $\begin{array}{r}4 \mathrm{I} \cdot 43 \\
6.25\end{array}$ & $\begin{array}{c}39.48 \\
5.95\end{array}$ & $\ldots$ & $\ldots$ & $\begin{array}{r}42.50 \\
6.80\end{array}$ & $\begin{array}{r}38 \cdot 23 \\
5 \cdot 25\end{array}$ & $\ldots$ & $\ldots$ & $\cdots$ & $\cdots$ \\
\hline $\mathrm{S}_{12}$ & $\begin{array}{r}38 \cdot 15 \\
1 \cdot 70\end{array}$ & $\begin{array}{c}34.96^{*} \\
0.93\end{array}$ & $\begin{array}{r}42 \cdot 05 \\
6 \cdot 90\end{array}$ & $\begin{array}{c}3^{8} \cdot 43 \\
5 \cdot 05\end{array}$ & $\cdots$ & $\cdots$ & $\begin{array}{r}4 \mathrm{r} \cdot 23 \\
5.65\end{array}$ & $\begin{array}{c}39 \cdot 05 \\
5.70\end{array}$ & $\cdots$ & $\cdots$ & $\ldots$ & \\
\hline $\mathrm{S}_{13}$ & $\begin{array}{c}38 \cdot 62^{*} \\
1 \cdot 63\end{array}$ & failed & $\begin{array}{c}40.94^{*} \\
5.47\end{array}$ & $\begin{array}{r}37.23 \\
5.25\end{array}$ & ... & $\ldots$ & $\begin{array}{c}4 \mathrm{I} \cdot 68 \\
5 \cdot 45\end{array}$ & $\begin{array}{r}3^{8 \cdot 18} \\
3.95\end{array}$ & $\ldots$ & $\ldots$ & $\ldots$ & $\ldots$ \\
\hline $\mathrm{S}_{4}$ & $\begin{array}{c}3^{8 \cdot} \cdot 54^{*} \\
4 \cdot 73\end{array}$ & $\ldots$ & $\begin{array}{c}4 \mathrm{r} \cdot 25 \\
6 \cdot 15\end{array}$ & $\begin{array}{c}37 \cdot 85 \\
6 \cdot 40\end{array}$ & $\ldots$ & $\cdots$ & $\begin{array}{r}40 \cdot 55 \\
5.90\end{array}$ & $\begin{array}{c}3^{8} \cdot 93 \\
4 \cdot 05\end{array}$ & $\ldots$ & $\ldots$ & $\ldots$ & $\ldots$ \\
\hline $\mathrm{S}_{15}$ & $\begin{array}{c}40 \cdot 4^{I^{*}} \\
3.55\end{array}$ & $\ldots$ & $\begin{array}{c}42.27^{*} \\
6.65\end{array}$ & $\begin{array}{r}3^{8} \cdot 15 \\
5 \cdot 5^{0}\end{array}$ & $\ldots$ & $\ldots$ & $\begin{array}{r}42 \cdot 30 \\
4 \cdot 60\end{array}$ & $\begin{array}{r}38 \cdot 35 \\
5 \cdot 10\end{array}$ & $\cdots$ & $\ldots$ & $\cdots$ & $\cdots$ \\
\hline Si 6 & $\begin{array}{c}3^{8} \cdot 25^{*} \\
5.00\end{array}$ & $\ldots$ & $\begin{array}{r}42 \cdot 03 \\
4.95\end{array}$ & $\begin{array}{r}38 \cdot 15 \\
6 \cdot 10\end{array}$ & $\ldots$ & $\cdots$ & $\begin{array}{r}42 \cdot 53 \\
6 \cdot 25\end{array}$ & $\begin{array}{c}3^{8 \cdot 43} \\
3 \cdot 45\end{array}$ & $\cdots$ & $\ldots$ & $\cdots$ & $\cdots$ \\
\hline$S_{17}$ & ... & $\cdots$ & $\begin{array}{r}4 \mathrm{I} \cdot 67 \\
6 \cdot 75\end{array}$ & $\begin{array}{c}35.52^{*} \\
2.85\end{array}$ & $\ldots$ & $\cdots$ & $\begin{array}{r}4 \mathrm{r} \cdot 43 \\
6.95\end{array}$ & $\begin{array}{c}36.92^{*} \\
5.63\end{array}$ & $\ldots$ & $\cdots$ & $\cdots$ & $\ldots$ \\
\hline
\end{tabular}

For further particulars, see table IA 
Four of these stocks were kindly supplied to us by $\mathrm{Mr}$ Wigan after they had been maintained for a year in the laboratory. They were homozygous respectively for the chromosome II's which we will denote as $A, B, C$ and $D$. These stocks and the lines to which they gave rise will be referred to as $\mathrm{A} / \mathrm{A}, \mathrm{B} / \mathrm{B}, \mathrm{C} / \mathrm{C}$ and $\mathrm{D} / \mathrm{D}$. All the six possible crosses were made between these four stocks to give the lines which will be called correspondingly $A / B, A / C, A / D, B / C$, $\mathrm{B} / \mathrm{D}$ and $\mathrm{G} / \mathrm{D}$.

Selection was practised for both increasing and decreasing numbers of abdominal chaetæ in all the ten lines, four homozygous and six heterozygous. The technique of the experiment differed slightly from that used by Mather and Harrison (1949). Each culture was the product of four parent flies, two females and two males, but only one culture was counted in each line in each generation. A second culture was raised but it was not used unless the first one gave too few flies for continuation of the line. Where available, twenty females and twenty males were taken for counting. The numbers of chaetæ were counted on the fourth and fifth abdominal segments and the counts pooled. The figures given in the tables are the means of the sex means of such pooled numbers, as were also used by Mather and Harrison (1949).

At times the first cultures failed to produce the desired twenty flies of each sex. These cases are denoted by an asterisk in table IA, where the data are summarised. When very few flies were available, no attempt was made to select, and the unselected mass was pooled for use as parents of the next generation. These are marked by a dagger in the table. When both cultures failed completely, resort was made to the previous generation for continuation of the line.

Normally the two flies of each sex with the highest (in the high lines) or lowest (in the low lines) counts were taken for use as parents of the next generation. Thus with twenty flies of each sex, the selection would use ro per cent. of the flies as effective parents. No selection was practised in the $F_{1}$ 's of the crosses, or in the corresponding generation in the four homozygous lines. In the $F_{2}$ 's, and in the corresponding generations of the homozygous lines, both high and low selections were made, so initiating the $\mathrm{H}$ and $\mathrm{L}$ lines which were subsequently kept distinct.

\section{THE HOMOZYGOUS LINES}

The data from the four homozygous lines are given in table IA, and the results of selection are shown graphically in fig. $\mathrm{I}$.

The behaviour under selection of lines $\mathrm{A} / \mathrm{A}$ and $\mathrm{C} / \mathrm{C}$ follows the pattern expected from earlier experience of selection in inbred lines (Mather, 1941; Mather and Wigan, 1942): no difference was established between the $\mathrm{H}$ and $\mathrm{L}$ lines up to $\mathrm{S} 6$ (i.e. the 6th generation of selection) in $\mathrm{A} / \mathrm{A}$ and $\mathrm{S} 8$ in $\mathrm{C} / \mathrm{C}$ when the selections ceased. The 
$\mathrm{L}$ line of A/A was carried on for three generations after A/A H ceased at $S 6$, and it continued to show no sign of change.

The first $\mathrm{H}$ selection from $\mathrm{D} / \mathrm{D}$ failed and the line was not restarted. It is thus impossible to make any comparison between $\mathrm{H}$ and $\mathrm{L}$ in this line. It is clear from table IA, however, that although the $\mathrm{L}$ line showed a slight downward drift there is no good evidence of it having a lower chaetæ count at $\mathrm{S}_{5}$ than at the beginning of the experiment. There is thus no clear indication that selection was anything but ineffective as expected.

Line B/B behaved differently from the rest in that it showed an unexpected response to selection. This first appeared at $\mathrm{S}_{4}$ and was complete at $\mathrm{S}_{5}$ : it thus occupied only two generations. From $\mathrm{S}_{5}$ to $\mathrm{S} 8$ no further change occurred. The change chiefly involved a response in the $L$ line, and, when complete, led to the lines differing by about 5 chaetæ. This response to selection must imply genetic differences which might have arisen by mutation during the progress of selection, or, of course, might have been present in the original stock from which the selection lines were begun. This stock had been homogenic when it was first made, but as we have already seen, it had been kept for a year before the selection experiments began. Thus mutation might have occurred in the stock before selection. This was tested by extracting from the unselected stock a new homozygous line. The purification process was as follows.

$$
\begin{aligned}
& \text { (stock) } \frac{\mathrm{B}}{\overline{\mathrm{B}}} \times \frac{\mathrm{C} y \mathrm{~L}^{4}}{\mathrm{P} m} ; \frac{\mathrm{S} b}{\mathrm{O} r} \text { (stock) } \\
& \frac{\mathrm{C} y \mathrm{~L}^{4}}{\mathrm{~B}} ; \frac{\mathrm{S} b}{\mathrm{O} r} \times \frac{\mathrm{C} y \mathrm{~L}^{4}}{\mathrm{P} m} ; \frac{\mathrm{S} b}{\mathrm{O} r} \\
& \frac{\mathrm{C} y \mathrm{~L}^{4}}{\mathrm{~B}} ; \frac{\mathrm{O} r}{\mathrm{O} r} \times \frac{{\mathrm{C} y \mathrm{~L}^{4}}^{4}}{\overline{\mathrm{B}}} ; \frac{\mathrm{O} r}{\mathrm{O} r} \\
& \frac{\mathrm{B}}{\mathrm{B}} ; \frac{\mathrm{O} r}{\mathrm{O} r} \text { (purified) }
\end{aligned}
$$

Where $\mathrm{O} r$ indicates a chromosome from our inbred Oregon stock.

This new (second) homozygous B/B line was selected in both directions for II generations but failed to show any response. In chaeta number it corresponds to the $\mathrm{L}$ line of the original $\mathrm{B} / \mathrm{B}$ selection from $\mathrm{S}_{5}-\mathrm{S} 8$ (table IA and fig. I).

The new $\mathrm{B} / \mathrm{B}$ line showed no change under selection so that mutation cannot be a frequent and persistent phenomenon in the $\mathrm{B} / \mathrm{B}$ stock. The $\mathrm{L}$ line of the original $\mathrm{B} / \mathrm{B}$ was only extracted and stabilised after some generations of selection and yet it corresponds exactly to the second $\mathrm{B} / \mathrm{B}$ line. Thus both the $\mathrm{L}$ line of first $\mathrm{B} / \mathrm{B}$ and the whole of the second $B / B$ must be presumed to have received the same genetic material and their only connection is via the original unselected stock. This genetic material was therefore present in 
that stock. The early cultures of first $\mathrm{B} / \mathrm{B}$ have, however, a higher chaeta number than either the $\mathrm{L}$ line derived from them or second B/B. This chaeta number was maintained and even increased slightly in $\mathrm{H}$ of the first $\mathrm{B} / \mathrm{B}$ line. Thus the initial cultures of the first $\mathrm{B} / \mathrm{B}$, and also the original unselected line, must have contained chromosomes which gave higher chaeta numbers than those stabilised by the L selection. Now cultures are the product of four parents,

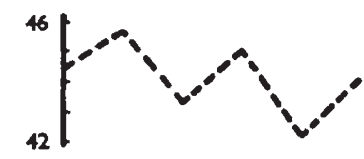

$D / D$
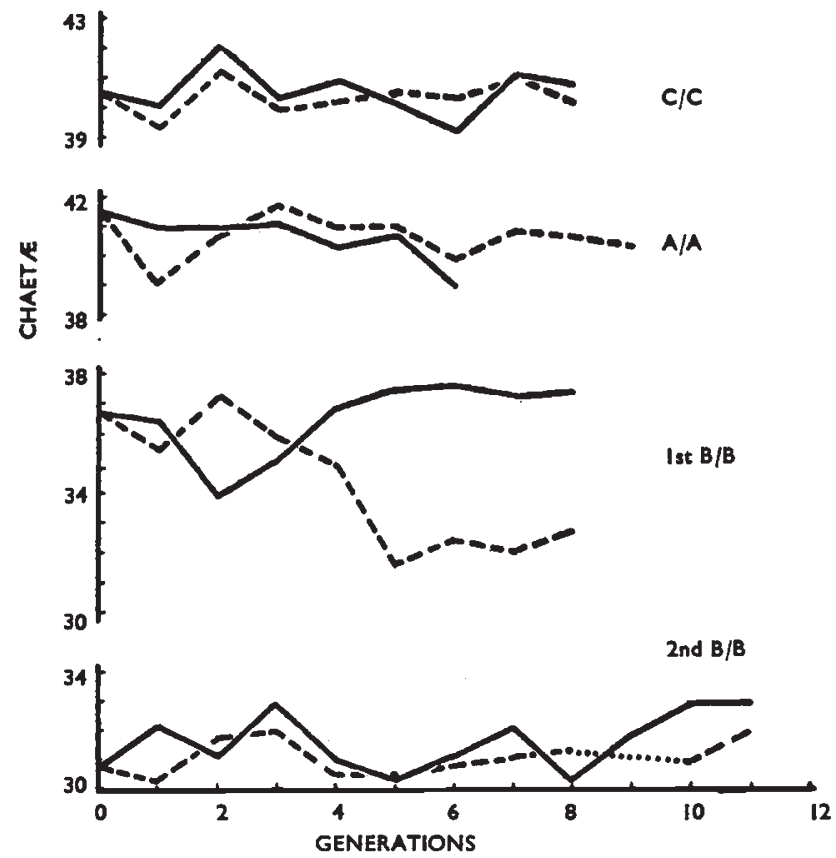

Fic. 1. - The effects of selection in the homozygous lines. Number of chaeta (mean of sex means) is plotted against generations of selection. The $\mathrm{H}$ selections are shown as solid and the $L$ selections as broken lines. A dotted line indicates the absence of observations for a generation.

2 females and 2 males, so that they contain 8 representatives of any chromosome. It is to be presumed that the sample of chromosomes with which first $\mathrm{B} / \mathrm{B}$ started was mixed but included very few, perhaps only one, giving the low chaeta number. Thus it would take a few generations before the $\mathrm{L}$ line would be extracted and stabilised at its low level, which would depart from the initial average chaeta number by much more than the $\mathrm{H}$ selection would do. It will be observed that the data do not permit any certainty that the change was in chromosome II of the original stock. The purification process did not give a line certainly homozygous for chromosome $\mathbf{X}$ and III from 
the $\mathrm{B} / \mathrm{B}$ stock, although it might well have achieved this result in addition to the controlled homozygosis of $\mathrm{B}$. If the second $\mathrm{B} / \mathrm{B}$ line had responded to selection or if it had not corresponded to $\mathrm{H}$ or $\mathrm{L}$ of the first $\mathrm{B} / \mathrm{B}$ line, some confidence could have been felt that chromosome $\mathrm{X}$ or III was involved in the change for it would then have been clear that the purification process, designed to deal with chromosome II, had not in fact been effective. Since, however, neither of these contingencies arose, uncertainty must persist as to whether the mutation was in chromosome II. In any case, as the original $\mathrm{B} / \mathrm{B}$ line was used in the crosses with $\mathrm{A} / \mathrm{A}, \mathrm{C} / \mathrm{C}$ and $\mathrm{D} / \mathrm{D}$, the interpretation of the results achieved by selection of the resulting three heterozygous lines must be somewhat in doubt.

Before passing on to consider the effect of selection on the heterozygous lines, certain differences between the homozygous lines must be observed. Table 2 shows the average numbers of chaetæ (mean of sex means) in all the lines, using families where at least 20 flies were available from the two sexes together. The $\mathrm{H}$ and $\mathrm{L}$ selections. are pooled in $\mathrm{A} / \mathrm{A}, \mathrm{C} / \mathrm{C}, \mathrm{D} / \mathrm{D}$ and the second $\mathrm{B} / \mathrm{B}$, where selection was ineffective. In the first $B / B$, the $H$ and $L$ lines are separated from $S_{I}$ on. Since no effect of selection was apparent before $S_{4}$, the inclusion of $S_{1}$ to $S_{3}$ in the separate lines must lead to a spuriously low value for the difference between them.

TABLE 2

Chaeta numbers in the homozygous lines

\begin{tabular}{|c|c|c|c|c|c|c|c|}
\hline \multirow{2}{*}{ Line } & & \multirow{2}{*}{$\mathrm{A} / \mathrm{A}$} & \multirow{2}{*}{$\mathrm{C} / \mathrm{C}$} & \multirow{2}{*}{$\mathrm{D} / \mathrm{D}$} & \multicolumn{2}{|c|}{ First B/B } & \multirow{2}{*}{$\begin{array}{l}\text { Second } \\
\text { B/B }\end{array}$} \\
\hline & & & & & $\mathrm{H}$ & L & \\
\hline Number of families & & 14 & 18 & 4 & 8 & 8 & 23 \\
\hline Mean chaeta number & - & $\begin{array}{c}40.63 \\
\pm 0.175\end{array}$ & $\begin{array}{c}40 \cdot 47 \\
\pm 0 \cdot 159\end{array}$ & $\begin{array}{c}43.72 \\
\pm 0.647\end{array}$ & $\begin{array}{c}36 \cdot 53 \\
\pm 0 \cdot 472\end{array}$ & $\begin{array}{c}34.23 \\
\pm 0.793\end{array}$ & $\begin{array}{c}31 \cdot 35 \\
\pm 0 \cdot 179\end{array}$ \\
\hline
\end{tabular}

The standard errors of the means were found empirically from the variation observed between families within the line.

The mean numbers of chaetæ of $\mathrm{A} / \mathrm{A}$ and $\mathrm{C} / \mathrm{C}$ do not differ significantly $\left(t_{[30]}=0.67 \mathrm{I}\right)$ but all other comparisons among $\mathrm{A} / \mathrm{A}$, $\mathrm{C} / \mathrm{C}, \mathrm{D} / \mathrm{D}$ and $\mathrm{B} / \mathrm{B}$ show significant differences. The various chromosome II's thus differ in their effects on chaeta number. The difference between the $\mathrm{H}$ and $\mathrm{L}$ lines of the first $\mathrm{B} / \mathrm{B}$ is barely significant on these data $\left(t_{[14]}=2 \cdot 496\right)$ and the difference between the second $\mathrm{B} / \mathrm{B}$ and the $\mathrm{L}$ line of the first $\mathrm{B} / \mathrm{B}$ is fully significant $\left(t_{[29]}=3.545\right)$. These results are, however, open to objection because, as noted above, the $\mathrm{H}$ and $\mathrm{L}$ lines of the first $\mathrm{B} / \mathrm{B}$ have been separated right from $\mathrm{S}_{\mathbf{r}}$ in table 2, whereas no response to selection appeared before $\mathrm{S}_{4}$. 
If we take only the data from $\mathrm{S}_{4}$ onwards in the first $\mathrm{B} / \mathrm{B}$, the mean numbers of chaetæ are $\mathrm{H}, 37 \cdot 33^{8}$, and $\mathrm{L}, 32 \cdot 808$. These differ significantly $\left(t_{[14]}=3.883\right)$ using the same estimates of error variation as in table 2. These estimates of error will, of course, themselves be too high since they will include the changes which have resulted from selection within the lines. The difference between the second $\mathrm{B} / \mathrm{B}$ and the new value of the mean of $L$ in the first $B / B$ appears not significant $\left(t_{[9]}=\mathrm{I} \cdot 433\right)$ but the significance may have been underassessed as a result of the spuriously high estimate of error variation in the $\mathrm{L}$ line. The extent of the over-estimation is not, however, clear and there can be little doubt that no difference exists between second $B / B$ and $L$ of first $B / B$.

The various homozygous lines have been compared in respect of their sex differences, using only families in which at least I 5 flies of each sex were available for comparison. D/D has been omitted from this comparison because it gave few families of the requisite size.

TABLE 3

Sex differences in the homozygous lines

\begin{tabular}{|c|c|c|c|c|c|}
\hline Line & & $\mathrm{A} / \mathrm{A}$ & $\mathrm{C} / \mathrm{C}$ & First B/B & Second B/B \\
\hline Number of families & . & 10 & 18 & 15 & 21 \\
\hline Sex difference & . $\quad$. & $\begin{array}{c}6 \cdot 77 \\
\pm 0 \cdot 274\end{array}$ & $\begin{array}{c}5.97 \\
\pm 0.204\end{array}$ & $\begin{array}{c}2 \cdot 43 \\
\pm 0 \cdot 341\end{array}$ & $\begin{array}{c}1 \cdot 13 \\
\pm 0 \cdot 288\end{array}$ \\
\hline
\end{tabular}

The error variances were estimated empirically from the variation between the different families of each line. Those for $A / A$ and $C / C$ were found to be very similar and so were pooled to give a joint estimate of error variation of $\mathrm{V}=0.750023$ based on 26 degrees of freedom. The error variances of the two $\mathrm{B} / \mathrm{B}$ lines $(\mathrm{H}$ and $\mathrm{L}$ being pooled in the first $\mathrm{B} / \mathrm{B}$ ) were similarly pooled to give a common estimate of $\mathrm{V}=\mathrm{I} \cdot 748 \mathrm{~g} \mathrm{I}$ based on 34 degrees of freedom. The standard errors of table 3 and the various tests of significance have been based on these pooled estimates of error variance.

There is a strong suggestion that $\mathrm{A} / \mathrm{A}$ and $\mathrm{C} / \mathrm{C}$ differ in their sex difference $\left(t_{[26]}=2 \cdot 359, \mathrm{P}=0.05-0.02\right)$. We have already seen that the $\mathrm{H}$ and $\mathrm{L}$ selections of the first $\mathrm{B} / \mathrm{B}$ show evidence of having departed in their sex difference. As expected the $L$ line of first $B / B$ does not differ significantly from the second $\mathrm{B} / \mathrm{B}\left(t_{[34]}=0.379\right)$. The contribution made by first $\mathrm{B} / \mathrm{B}$ to the estimate of error variance will be inflated by the differences between the $\mathrm{H}$ and $\mathrm{L}$ lines that it contains ; but this inflation is hardly likely to be marking a difference between $\mathrm{L}$ of first $\mathrm{B} / \mathrm{B}$ and second $\mathrm{B} / \mathrm{B}$ when $t$ as calculated is so small.

The differences between $\mathrm{A} / \mathrm{A}$ and $\mathrm{C} / \mathrm{C}$ and between the various $\mathrm{B} / \mathrm{B}$ lines prohibit a simple comparison between $\mathrm{A} / \mathrm{A}$ and $\mathrm{C} / \mathrm{C}$ on 
the one hand, and all the $\mathrm{B} / \mathrm{B}$ lines on the other. The great disparity between the sex differences of the $B / B$ lines and $A / A$ and $C / C$ can leave, however, little doubt that the $\mathrm{B}$ chromosome differs from the others in the sex difference it produces. It will be observed, too, that there is a difference in the variability of the sex difference. Even allowing for the inflation of the $\mathrm{B} / \mathrm{B}$ error variation, the sex difference produced by the $\mathrm{B}$ chromosome seems definitely more variable than those of the A and C chromosomes.

One further comparison was made amongst the homozygous lines, viz. in their fertilities. This was measured very crudely by dividing the cultures into two classes: those that gave at least 20 flies of each sex and those that failed to do so. When a line failed (as opposed to being terminated deliberately) the failure was counted as one culture not giving 20 flies of each sex, and thereafter omitted from consideration. The results are given in table 4 .

TABLE 4

Fertilities of the homozygous lines

\begin{tabular}{|c|c|c|c|c|c|}
\hline \multirow{2}{*}{ Line } & \multirow{2}{*}{$\mathrm{A} / \mathrm{A}$} & \multicolumn{2}{|c|}{$\mathrm{B} / \mathrm{B}$} & \multirow{2}{*}{$\mathrm{C} / \mathrm{C}$} & \multirow{2}{*}{$\mathrm{D} / \mathrm{D}$} \\
\hline & & I & 2 & & \\
\hline Cultures giving 20 flies of each sex & 6 & 12 & 17 & 12 & o \\
\hline Cultures not giving 20 flies of each sex & Io & 6 & 6 & 6 & 7 \\
\hline Total & 16 & 18 & 23 & 18 & 7 \\
\hline
\end{tabular}

A test of homogeneity gives $\chi_{[4]}^{2}=I_{5} .844$ with $\mathrm{P}=0 . \mathrm{OI}-\mathrm{O} \cdot 0 \mathrm{OI}$. The main difference in fertility seems to lie between $D / D$ and the rest. $\mathrm{A} / \mathrm{A}$ and $\mathrm{C} / \mathrm{C}$ show a suggestion of a difference in fertility but the evidence is not conclusive $\left(\chi_{[1]}^{2}=2 \cdot 89^{2}\right.$, with $\left.\mathrm{P}=0.10-0.05\right)$.

These various tests show that no two of the chromosome II's can be regarded as alike in their effects. Apart from A and $\mathrm{C}$ they differ in their effects on mean chaeta number, $D$ giving the highest, $\mathrm{B}$ the lowest and $\mathrm{A}$ and $\mathrm{C}$ being intermediate. There are also differences in the sex differences in chaeta number produced by the chromosomes, and in this respect even $\mathrm{A}$ and $\mathrm{C}$ appear to differ. $\mathrm{D}$ gives flies of lower fertility than the rest of the chromosomes. Finally the lines fail, as expected, to respond to selection, apart from the difference which developed in the first $B / B$ and which was traceable to its parent unselected stock.

\section{THE HETEROZYGOUS LINES}

As already noted, the four homozygous lines were intercrossed to give the six possible heterozygous lines, $\mathrm{A} / \mathrm{B}, \mathrm{A} / \mathrm{C}, \mathrm{A} / \mathrm{D}, \mathrm{B} / \mathrm{C}, \mathrm{B} / \mathrm{D}$ and $C / D$. These were each subjected to selection for high $(H)$ and 


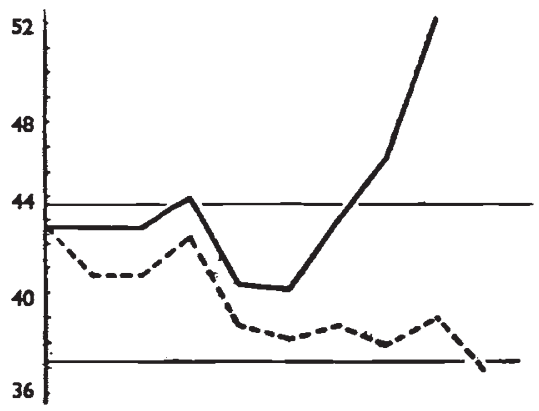

B/D
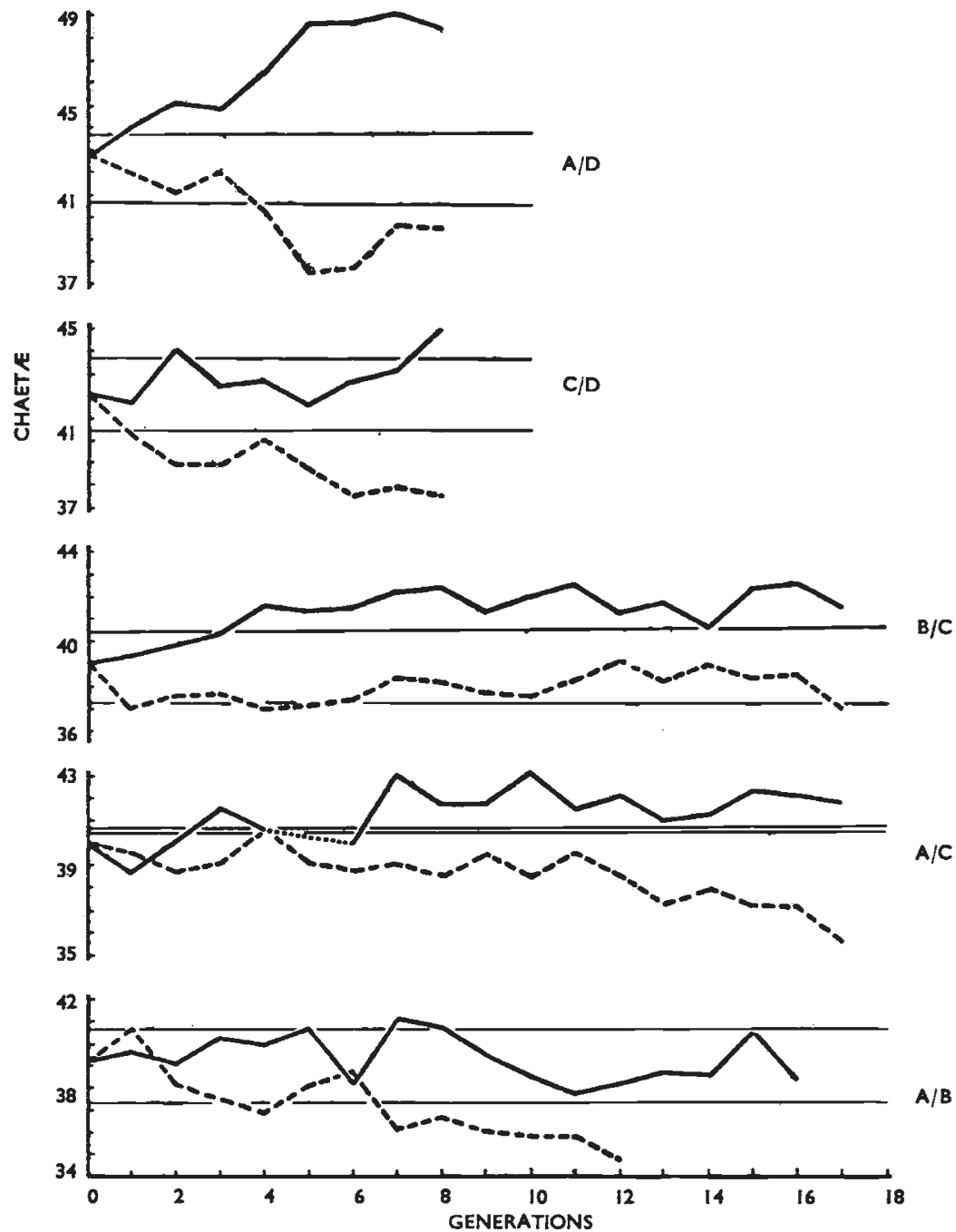

Fig. 2.-The effects of selection in the heterozygous lines. Number of chaetre (mean of sex means) is plotted against generation of selection. The $\mathrm{H}$ selections are shown as solid and the $\mathrm{L}$ selections as broken lines. A dotted line indicated the absence of observations for a generation. The numbers of chaetæo of the parental lines (averages over all the generations shown in fig. $\mathrm{x}$ ) are indicated by thinner horizontal lines. The average of the $\mathrm{H}$ selection of first $\mathrm{B} / \mathrm{B}$ (generations $\mathrm{S}_{4}-\mathrm{S} 8$ ) is used for the $\mathrm{B} / \mathrm{B}$ line. The low level of this line, found as the average of second $B / B$, is $31 \cdot 35$. 
low (L) numbers of abdominal chaetæ from $F_{2}$ onwards. The results of selection are given in table I B and in fig. 2.

The mean chaeta numbers of the $F_{1}$ and $F_{2}$ generations were closely similar in each cross. Their average is compared for each cross with the chaeta numbers of the parental lines in table 5. Figures are given for both the $\mathrm{H}$ level (average of $\mathrm{S}_{4}-\mathrm{S} 8$ in $\mathrm{H}$ selection of Ist $B / B$ ) and, in brackets, the $L$ level (average of 2 nd $B / B$ ) in the case of the $B / B$ parent.

TABLE 5

Comparison of the homozygous lines and their hybrids

\begin{tabular}{|c|c|c|c|c|c|c|}
\hline Cross & $A / B$ & $\mathrm{~A} / \mathrm{C}$ & $\mathrm{A} / \mathrm{D}$ & $\mathrm{B} / \mathrm{C}$ & B/D & $\mathrm{C} / \mathrm{D}$ \\
\hline \multirow[t]{2}{*}{ Parents . } & & $4^{0} \cdot 63$ & $4^{0} \cdot 63$ & $\begin{array}{c}37 \cdot 34 \\
(31 \cdot 35)\end{array}$ & $\begin{array}{c}37 \cdot 34 \\
(31 \cdot 35)\end{array}$ & $4^{\circ} \cdot 47$ \\
\hline & $\begin{array}{c}37 \cdot 34 \\
(31 \cdot 35)\end{array}$ & $4^{0 \cdot 47}$ & $43 \cdot 72$ & $40 \cdot 47$ & 43.72 & $43 \cdot 7^{2}$ \\
\hline$F_{1}$ and $F_{2}$ & $39 \cdot 23$ & 39.99 & $4^{2} \cdot 78$ & $39 \cdot 98$ & $42 \cdot 73$ & $42 \cdot 17$ \\
\hline Mid-parent & $\begin{array}{c}38 \cdot 99 \\
(35 \cdot 99)\end{array}$ & $4^{0 \cdot 55}$ & $4^{2} \cdot 18$ & $\begin{array}{c}38 \cdot 9 \mathrm{r} \\
(35.9 \mathrm{I})\end{array}$ & $\begin{array}{r}40 \cdot 53 \\
(37 \cdot 53)\end{array}$ & $4^{2} \cdot 10$ \\
\hline
\end{tabular}

In all cases, except $A / C$, the mean of $F_{1}$ and $F_{2}$ falls between the parental values, and lines $\mathrm{A} / \mathrm{A}$ and $\mathrm{C} / \mathrm{C}$ are so similar in their mean numbers of chaetx that their $F_{1}$ and $F_{2}$ might well be expected to fall a little outside the parental range. In $A / C, A / D$ and $C / D$ the $F_{1}$ and $F_{2}$ average falls reasonably close to the mid-parent value, found as the average of the two parental means. In the three crosses which involve $B$, the $F_{1}$ and $F_{2}$ average is above the mid-parent even when the $\mathrm{H}$ value is taken for the $\mathrm{B} / \mathrm{B}$ parent. The difference is not large in $A / B$ when the $H$ value is used for $B / B$; but it is considerable in $B / C$ and $B / D$. This suggests that chromosome $B$ has a lower potency than $\mathrm{C}$ and $\mathrm{D}$ at least.

The responses to selection vary amongst the crosses (fig. 2). It shows the greatest combination of speed and size in A/D. Here both the parental limits had been transgressed by $\mathrm{S}_{4}$; and by $\mathrm{S} 8$, when the line was terminated, the difference between $\mathrm{H}$ and $\mathrm{L}$ was nearly Io chaetæ, as compared with a difference of about 3 between the parents. Glearly there was a considerable amount of potential variability in this cross. It was released fairly smoothly and at a speed which made progress under selection over half as fast as that found by Mather and Harrison after crossing two distinct stocks, Oregon and Samarkand. Two chromosomes of the wild population carry, therefore, differences which can lead to remarkably rapid change under selection, these differences being largely balanced within the chromosomes.

Progress under selection in $\mathrm{C} / \mathrm{D}$ is slower and smaller than in $\mathrm{A} / \mathrm{D}$. The difference between $\mathrm{C} / \mathrm{D}$ and $\mathrm{A} / \mathrm{D}$ is especially noticeable in the 
failure of $\mathrm{H}$ from the former to pass the level of the upper parent before S8. Nevertheless, it would appear likely that $\mathrm{H}$ and $\mathrm{L}$ were still diverging when the line was terminated at S8, and a difference of some 6 chaetæ had been established between them by that time.

The divergence of $\mathrm{H}$ and $\mathrm{L}$ in $\mathrm{B} / \mathrm{D}$ was very small before S6, but after that time it developed rapidly, largely because of progress by $\mathrm{H}$, which at $\mathrm{S} 7$ had passed the upper parental level. The potential variability here seems to be no less than in $A / D$ (in fact at $S 8$ the difference between $\mathrm{H}$ and $\mathrm{L}$ of $\mathrm{B} / \mathrm{D}$ is about $\mathrm{I} 2$ chaetæ), but it seems more difficult to release. Presumably the balancing genes are more tightly linked than in $\mathrm{A} / \mathrm{D}$.

It will be observed that the $\mathrm{L}$ selection of $\mathrm{B} / \mathrm{D}$ failed to reach the lower parental value before $\mathrm{S}_{9}$, taking the $\mathrm{H}$ value as characteristic of $\mathrm{B} / \mathrm{B}$. Evidently the potential variability became more readily available to high than to low selection. This may, of course, have been due to the chance occurrence of some important but rare recombination earlier in the high line, than in the low line. It might, however, be due to the low recombinant chromosome being less viable, or at least less able to compete with its immediate parent chromosomes, than was its high counterpart. If we take the $\mathrm{L}$ value as characteristic of $B / B$, the $L$ selection of $B / D$ fails to reach the parental level, and these conclusions concerning the availability of potential variability are, of course, strengthened.

The $A / B$ and $B / C$ lines require little comment. $H$ of $B / C$ just exceeds the $\mathrm{C} / \mathrm{C}$ level, and $\mathrm{L}$ of $\mathrm{A} / \mathrm{B}$ just transgresses the $\mathrm{B} / \mathrm{B}$ level (taking the $\mathrm{H}$ value for $\mathrm{B} / \mathrm{B}$ ) so suggesting a certain amount of potential variability in each cross. This conclusion is strengthened by the rather slow progress of both these selection lines in their early stages.

The homozygous lines $\mathrm{A} / \mathrm{A}$ and $\mathrm{C} / \mathrm{C}$ had mean chaeta numbers between which no significant difference could be detected. That chromosomes $\mathrm{A}$ and $\mathrm{C}$ were not, however, genetically equivalent was attested by a difference between the sex difference in chaeta number of the two lines. The genetical difference between the chromosomes is shown to extend to the genes affecting mean chaeta number itself by the results of selection in $\mathrm{A} / \mathrm{C}$. A difference between chaeta number in the $\mathrm{H}$ and $\mathrm{L}$ selections is clear after $\mathrm{S}_{7}$ and it seems to be increasing in magnitude right up to the $\mathrm{S}_{\mathrm{I}} 7$ when the lines were terminated. By that time a difference of some 5 chaetæ had been established. Evidently, though displaying balances indistinguishable from one another, chromosomes $\mathrm{A}$ and $\mathrm{C}$ contained between them sufficient potential variability to permit marked, even if not large, advances under selection.

The foregoing observations refer to the mean chaeta number, found as the mean of the sex means. The sex difference in chaeta number in the heterozygous lines is also informative. The results, as they relate to the sex difference, are summarised in table 6 . 
As before the standard errors have been found empirically from the differences amongst the individual families in each line.

TABLE 6

Sex differences in chaeta number in the heterozygous lines



The first point noticeable in this table is that the sex differences in the three lines one of whose parents was B/B are, with one exception, lower than those of the rest of the selections. The low sex difference of $\mathrm{B} / \mathrm{B}$ is passed on to its offspring. The sex differences of the various lines descended from $\mathrm{B} / \mathrm{B}$ are, however, all higher than the sex difference of $\mathrm{B} / \mathrm{B}$ itself. If we compare them with the first $\mathrm{B} / \mathrm{B}$ taken as a whole (i.e. pooling the $\mathrm{H}$ and $\mathrm{L}$ lines within $\mathrm{B} / \mathrm{B}$ ) all of the six lines $(\mathrm{H}$ and $\mathrm{L}$ from $\mathrm{A} / \mathrm{B}, \mathrm{B} / \mathrm{C}$ and $\mathrm{B} / \mathrm{D})$ significantly exceed the parent in sex difference. If the comparison is made with the $\mathrm{H}$ line of first $\mathrm{B} / \mathrm{B}$ the significance is lost, doubtless because only three families are available for the estimation of sex difference in $\mathrm{H}$ of the first $\mathrm{B} / \mathrm{B}$. The six heterozygous lines nevertheless all exceed $\mathrm{H}$ of first $\mathrm{B} / \mathrm{B}$ in mean sex difference, even if not significantly, and we may feel some confidence that in fact none of the six had the genic constitution of $\mathrm{B} / \mathrm{B}$ in this respect. This is not remarkable in the $\mathrm{H}$ lines of $\mathrm{A} / \mathrm{B}$, $\mathrm{B} / \mathrm{C}$ and $\mathrm{B} / \mathrm{D}$; but it is noteworthy in the corresponding $\mathrm{L}$ lines. It shows us that selection has not merely restored homozygosity for the $\mathrm{B}$ chromosomes in these $\mathrm{L}$ lines. There has been some recombination of the genes affecting the sex difference, recombination which may or may not have been effective in releasing potential variability in respect of the mean chaeta number.

The $\mathrm{H}$ line of $\mathrm{A} / \mathrm{B}$ also has a sex difference significantly lower than that of $\mathrm{A} / \mathrm{A}$, this being doubtless related to the failure of this line to maintain consistently a level as high as the $\mathrm{A} / \mathrm{A}$ parent in mean chaeta number. The $\mathrm{H}$ line of $\mathrm{B} / \mathrm{C}$ is a little lower than that of $\mathrm{C} / \mathrm{C}$, but not significantly so. So far as sex difference goes, therefore, $\mathrm{H}$ from $\mathrm{B} / \mathrm{C}$ could be carrying the $\mathrm{C}$ chromosome in homozygous condition. This is, however, unlikely as its mean chaeta number slightly exceeds that of $\mathrm{C} / \mathrm{C}$ (fig. 2). The remaining sex differences are not informative.

The fertilities of the various heterozygous lines, found in the same way as used earlier for the homozygous lines, are given in table 7 . 
It is obvious from the table that the different lines differed in their fertilities. In general those lines one of whose parents was $\mathrm{A} / \mathrm{A}$ have a lower fertility than those not descended from A/A. Only one

TABLE 7

\begin{tabular}{|c|c|c|c|c|c|c|c|c|c|c|c|c|c|}
\hline \multirow{2}{*}{ Line } & \multicolumn{2}{|c|}{ A/B } & \multicolumn{2}{|c|}{ A/C } & \multicolumn{2}{|c|}{ A/D } & \multicolumn{2}{|c|}{ B/C } & \multicolumn{2}{|c|}{ B/D } & \multicolumn{2}{c|}{ C/D } \\
\cline { 2 - 8 } & H & L & H & L & H & L & H & L & H & L & H & L \\
\hline $\begin{array}{c}\text { Cultures giving 20 flies of } \\
\text { each sex }\end{array}$ & 9 & 7 & 9 & 16 & 4 & 2 & 17 & 16 & 7 & 8 & 8 & 6 \\
$\begin{array}{c}\text { Cultures not giving 20 flies } \\
\text { of each sex } \\
\text { Total . }\end{array}$ & 7 & 5 & 8 & 1 & 4 & 6 & 0 & I & I & I & 0 & 2 \\
\hline
\end{tabular}

comparison, however, requires special notice. The $\mathrm{H}$ and $\mathrm{L}$ lines of A/C differ significantly in their proportions of cultures which failed to give 20 flies of each sex $\left(x_{[1]}^{2}=7 \cdot 404\right)$. Thus the parental lines $\mathrm{A} / \mathrm{A}$ and $\mathrm{C} / \mathrm{C}$, from which these two selections are descended, cannot have been genetically alike. This evidence reinforces the conclusion already reached from consideration of the sex differences in $\mathrm{A} / \mathrm{A}$ and $\mathrm{C} / \mathrm{C}$, and of the effects of selection of the mean chaeta number in $\mathrm{A} / \mathrm{C}$.

\section{THE GENETIC DIVERSITY OF THE FOUR CHROMOSOMES}

It is clear from the observations described above that all the four second chromosomes, $\mathrm{A}, \mathrm{B}, \mathrm{C}$ and $\mathrm{D}$, must differ in their genic content. $\mathrm{B}$ and $\mathrm{D}$ obviously differ from one another and from $\mathrm{A}$ and $\mathrm{C}$ in respect of their genes controlling mean chaeta number. Lines $A / A$ and $\mathrm{C} / \mathrm{C}$ give mean chaeta numbers which do not differ significantly; but they are not alike in their average sex differences in chaeta number. $B$ also differs from both $A$ and $C$ in this latter respect. Few observations are available for $\mathrm{D} / \mathrm{D}$ in respect of sex difference, but this line has a lower fertility than the rest.

The behaviour of the heterozygous lines under selection reinforces and extends the conclusions from observation of the homozygous lines. In interpreting the reactions of the heterozygous lines to selection, it is assumed that their changes are to be traced to selection of differences existing between the chromosomes of the parental lines, and that they are not due to selection of differences which have arisen de novo within the heterozygous lines after their origin by crossing. Previous experience had accorded with this view, it having been observed in particular that :-

(i) the speed and extent of advance under selection is the greater the more widely different, in respect of gene content, the parental 
lines are expected from their origin to be (Mather, I94I ; Sismanidis, 1942); (ii) the changes wrought by selection have a determinacy which would be difficult to understand if they depended on differences arising by mutation (Sismanidis, 1942; Mather and Harrison, 1949); (iii) change in homozygous lines, where selection must utilise variation arising de novo, is very slow (Mather, I94I; Mather and Wigan, 1942).

The present observations on the reaction to selection of the four homozygous lines adds further to our information in respect of point (iii). Lines $\mathrm{A} / \mathrm{A}$ and $\mathrm{C} / \mathrm{C}$ showed the expected absence of change. Line $\mathrm{D} / \mathrm{D}$ was uninformative owing to failure of its $\mathrm{H}$ selection. Its $\mathrm{L}$ selection might be regarded as having fallen slightly in mean chaeta number ; but such an inference is unreliable in view of the absence of the corresponding $\mathrm{H}$ line and also in view of the low fertility of the L line itself. D/D could not be fairly regarded as contradicting other experience. Line $\mathrm{B} / \mathrm{B}$ offers, however, a more serious objection. There is no doubt that its $\mathrm{L}$ selection fell. Furthermore a second, purified $\mathrm{B} / \mathrm{B}$ line, which seemed to correspond to $\mathrm{L}$ of the first $B / B$, was stable under eleven generations of selection. This change in $\mathrm{L}$ of first $\mathrm{B} / \mathrm{B}$ can, as we have seen, be attributed to mutation in the original stock; but it does emphasise that our assumption, of change under selection in heterozygous lines being traceable to differences between the parents, is essentially statistical in its justification. Mutation does occur and can lead to change under selection. An individual case of change could be ascribed to mutation ; but the number, speed, size and determinacy of changes under selection in cross-bred lines are such that the vast majority of such changes cannot be ascribed to mutation. So we must assume that they are dependent on original differences between the parents.

It will therefore be assumed that selection in the heterozygous lines reveals differences between the chromosomes of the homozygous lines from which they are selected; though a special caution is perhaps necessary in interpreting the changes in $A / B, B / C$ and $B / D$. In general the evidence from these lines is most economically interpreted on the assumption that the usual $B / B$ stock contributed its high rather than its low chromosome to them. The response to selection in $\mathrm{A} / \mathrm{C}$, interpreted on this basis, confirms the genic difference between chromosomes $\mathrm{A}$ and $\mathrm{G}$, and indeed shows it to extend even to a character in respect of which the two chromosomes have indistinguishable overall balances. Their differences constitute potential as opposed to free variability in mean chaeta number. The existence of potential variability is also revealed by the behaviour of the three lines descended from $\mathrm{D} / \mathrm{D}$. In every case the $\mathrm{H}$ selection transcended the upper parent $\mathrm{D} / \mathrm{D}$, though only by a little in $\mathrm{C} / \mathrm{D}$. The. low parent was passed by the $L$ selection in $A / D$ and $C / D$; even if not in $B / D$. The occurrence of partially balanced differences between $D$ and the other three chromosomes is thus clear, and what is more, 
the difference established between $\mathrm{H}$ and $\mathrm{L}$ during eight generations in $\mathrm{A} / \mathrm{D}$ indicates that this store of potential variability is greater than the free variation expressed as the observable differences between $\mathrm{A} / \mathrm{A}$ and $\mathrm{D} / \mathrm{D}$, great though this latter is. In general, the differences between $\mathrm{H}$ and $\mathrm{L}$ selections are greater than the parental differences except in $\mathrm{A} / \mathrm{B}$ and $\mathrm{B} / \mathrm{C}$. And, in these cases, as we have seen, selection did not re-extract chromosomes similar in genic content to both the parents, so that even here we have evidence of potential variability. Great as the phenotypic differences are between the homozygous lines, the genetic differences between their chromosomes are greater. Potential as well as free variability exists and is revealed by relatively short programmes of selection. There can be little doubt, when all the data are taken into account, that this small population of four chromosomes carried within it the genetic materials necessary for giving differences of 20 chaetæ or more, i.e. at least a 25 per cent. change of mean chaeta number in each direction.

The four chromosomes had been kept in the laboratory for a year between collection in the wild and testing. The question therefore arises as to how far the above conclusions can apply to the original wild chromosomes. There was no evidence of heterogeneity in $A / A$ and $C / C$, and hence none of any change occurring in the laboratory. The evidence about $\mathrm{D} / \mathrm{D}$ is much less complete but it at least gives no reliable indication of change. $\mathrm{B} / \mathrm{B}$ undoubtedly did mutate during its period in the laboratory. We have, however, assumed above that it contributed to the heterozygous lines its high chaeta producing chromosome, i.e. the chromosome showing the lesser difference from $\mathrm{A}, \mathrm{C}$ and $\mathrm{D}$. There is thus no reason to doubt that the conclusions relating to polygenic differences among the four chromosomes used in the test would apply to the four chromosomes originally collected from the wild.

That the variation in mean chaeta number is under polygenic control becomes clear if we enquire into the minimum number of genes needed to explain the differences observed in this character. $\mathrm{D} / \mathrm{D}$ and $\mathrm{B} / \mathrm{B}$ differ from one another as well as from $\mathrm{A} / \mathrm{A}$ and $\mathrm{C} / \mathrm{C}$. At least two genes must be postulated immediately. Now chromosomes $A$ and $\mathrm{C}$ are not alike in genic content though alike in chaeta number. They must differ in at least two genes, the differences being balanced thus +- and -+ . D cannot differ from $\mathrm{A}$ and $\mathrm{C}$ merely by carrying the corresponding ++ combination because the $\mathrm{H}$ and $\mathrm{L}$ selection of $\mathrm{A} / \mathrm{D}$ transcend the $\mathrm{D} / \mathrm{D}$ and $\mathrm{A} / \mathrm{A}$ levels respectively and the $\mathrm{L}$ selection of $\mathrm{C} / \mathrm{D}$ transcends the level of $\mathrm{C} / \mathrm{C}$. The difference between $\mathrm{D}$ on the one hand and $\mathrm{A}$ and $\mathrm{C}$ on the other requires therefore at least one gene additional to the two in which $\mathrm{A}$ and $\mathrm{C}$ are assumed to differ. A similar argument applies in respect of $\mathrm{B}$. This cannot carry merely the - - combination of the genes distinguishing $\mathrm{A}$ and $\mathrm{C}$, for the $\mathrm{L}$ selection from $\mathrm{A} / \mathrm{B}$ seems not to be the same as $\mathrm{B} / \mathrm{B}$, and the $\mathrm{H}$ selection for $\mathrm{B} / \mathrm{C}$ transcends the level of $\mathrm{C} / \mathrm{C}$. Thus at 
least four genes are required to explain the differences among $\mathrm{A}$, $\mathrm{B}, \mathrm{C}$ and $\mathrm{D}$. To these must be added the determinant which mutated in the original $\mathrm{B} / \mathrm{B}$ stock, bringing the total up to five.

It would be easy to argue that there is evidence of the widening between the $\mathrm{H}$ and $\mathrm{L}$ lines from $\mathrm{A} / \mathrm{C}$ being too prolonged to be fairly ascribable to a single recombination between two gene differences; and that the same is true of $\mathrm{C} / \mathrm{D}$ and $\mathrm{B} / \mathrm{D}$ to name two others. In this way three further differences would be added. But even taking the bare minimum of five differences in these second chromosomes (assuming the change in $\mathrm{B} / \mathrm{B}$ to be due to a gene in chromosome II), it is clear that the variation must be regarded as polygenic. It must be remembered, too, that Mather and Harrison (1949) found evidence of at least two gene differences affecting this character in chromosome $\mathrm{X}$ and at least three in chromosome III. Gene differences are, in fact, ubiquitous and it is pointless to argue whether there are only ten (which good fortune has enabled us to unearth so readily) or whether there are really a hundred of which the ten are a chance sample; and whether the ten differences are in single genes or in compound effective factors (Mather, I949). Finally, these differences are all unassociated with any known major mutations : they occur between flies all of which are wild type, even if some of their combinations would put the flies at a marked disadvantage in the wild.

\section{SUMMARY}

Four second chromosomes were extracted by breeding from flies taken on an apple dump in Essex. Four lines were made up, differing by being homozygous for these second chromosomes respectively, but being otherwise alike in having chromosomes $\mathrm{X}$ and III from the laboratory's standard inbred Oregon stock. The six heterozygous lines possible from crossing four such homozygous stocks were also made. The homozygous stocks had to be maintained unselected in the laboratory for a year before the experiments began.

Selection was practised in both homozygous and heterozygous lines for increased and decreased numbers of abdominal chaetæ.

No response to selection was observed in two of the homozygous lines. The data were incomplete for a third one, but here, too, no clear evidence of change under selection was obtained. The fourth line responded to low selection in the middle of the experiment but was stable subsequently. After purification from the original unselected stock the line also failed to show any further response. This response is therefore attributed to a non-recurrent mutation in the original stock, between its extraction and its use in the experiments. That the chromosomes distinguishing these four lines must all have been different genetically is shown by observations on mean numbers of abdominal chaetæ, sex difference in number of abdominal chaetæ, and fertility. 
The responses to selection in the heterozygous lines confirm the genetical differences among the chromosomes in respect of chaeta number, and further show that much of the genetical variability was of the potential kind, being hidden in the form of balanced or partially balanced combinations of genes. It seems likely that the four chromosomes contained amongst them genetic differences sufficient to permit relatively rapid increase and decrease of the number of chaetæ by 25 per cent.

The chromosomes tested were separated by several generations from the wild; but there is no indication of change between collection and experiment other than in one stock as already mentioned. Thus the chromosomes as tested may be fairly regarded as representing chromosomes collected from the wild.

At least five genes must be postulated in chromosome II to account for the differences and changes of chaeta number observed in the experiments. Taking earlier experience into account, at least ten genes must be postulated in the whole nucleus. It is very unlikely that the number of genes is in fact as low as this minimum.

\section{REFERENCES}

JONES, D. F. 1945. Heterosis resulting from degenerative changes. Genetics, 30, 527-542.

MAtheR, K. 1941. Variation and selection of polygenic characters. F. Genet., 4I, I $59^{-1} 93$.

MATHER, K. 1949. Biometrical Genetics. London: Methuen.

MATHER, K., AND HARRISON, B. J. 1949. The manifold effect of selection. Heredity, $3,1-52$ and $131-162$.

MATHER, K., AND WIGAN, L. G. 1942. The selection of invisible mutations. P.R.S, $\mathrm{B}, 131,50-64$.

SISMANIDIs, A. 1942. Selection for an almost invariable character in Drosophila. 7. Genet., 44, 204-215.

WIGAN, L. G. 194I. Polygenic variability in wild Drosophila melanogaster. Nature, $148,373$.

WIGAN, L. G. 1948. Fohn Innes Horticultural Institution. 38th Annual Report, pp. 14-15. 